\title{
Effects of ras transformation on the induction of the IL-1 receptor related T1 gene in response to mitogens, anisomycin, IL-1 and TNF $\alpha$
}

\author{
Niels Bech Laursen ${ }^{1,2}$, Reto Kessler ${ }^{1}$, Erika Fröhli ${ }^{1}$ and Roman Klemenz ${ }^{1}$ \\ ${ }^{1}$ Division of Cancer Research, Department of Pathology, University Hospital of Zurich, Schmelzbergstrasse 12, CH-8091 Zurich, \\ Switzerland
}

The $T 1$ gene gives rise to two transcripts encoding a $62 \mathrm{kDa}$ membrane-bound and a $37 \mathrm{kDa}$ secreted protein with similarity to the type I IL-1 receptor. It is weakly expressed in proliferating but not in resting fibroblasts and is strongly induced during the entry of quiescent cells into the cell cycle. Here we show that the $T 1$ gene is also transcriptionally activated in response to the treatment of fibroblasts with cycloheximide and anisomycin. These protein synthesis inhibitors are known to stimulate the JNK and p38/RK signal transduction pathways. We provide evidence that anisomycin triggers $T 1$ gene induction through the stimulation of the p38/RK MAP kinase. This observation is in line with our finding that physiological activators of the $\mathrm{p38} / \mathrm{RK}$ pathway, the proinflammatory cytokines IL-1 and TNF $\alpha$, stimulate $T 1$ gene expression efficiently. Growth factor mediated $T 1$ gene induction is a delayed early event, requiring ongoing protein synthesis. In contrast, anisomycin induces $T 1$ gene expression at concentrations which block translation completely. Thus, transcriptional induction of the $T 1$ gene via the $\mathrm{p38} / \mathrm{RK}$ pathway is an immediate early event not requiring de novo protein synthesis. The $T 1$ gene is strongly induced by various mitogens in quiescent NIH3T3 fibroblasts but not in ras transformed NIH3T3 cells. In contrast, all of the three tested agent which activate the p38/RK pathway, IL-1, TNF $\alpha$, and anisomycin led to strong $T 1$ gene expression in normal and ras transformed NIH3T3 cells alike. Thus, the $T 1$ gene can be induced through the activation of at least two MAP kinase pathways: signaling through the ERK pathway can occcur in normal but not in ras transformed NIH3T3 cells, whereas the signaling through the p38/RK pathway is not affected by ras transformation.

Keywords: anisomycin; IL-1R family; IL-1; TNF $\alpha$; MAP kinases; SB203580; signal transduction pathway; ras oncogene

\section{Introduction}

$T 1$, also known as ST2 and DER4, was identified as a gene activated by growth factors and the induced expression of the Ha-ras or v-mos oncogenes in murine fibroblasts (Klemenz et al., 1989; Tominaga, 1989; Werenskiold et al., 1989; Lanahan et al., 1992). Later,

Correspondence: R Klemenz

${ }^{2}$ Present address: Laboratory for Gene Expression, Dept. of Molecular and Structural Biology, University of Aarhus, Forskerparken, Gustav Wieds Vej 10, DK-8000 Aarhus C., Denmark Received 15 April 1997; revised 27 August 1997; accepted 27 August 1997 the human and rat homolog have been isolated (Tominaga et al., 1992; Bergers et al., 1994).

$T 1$ is transcribed into two mRNA species of $2.7 \mathrm{~kb}$ and $5 \mathrm{~kb}$ which arise from alternative $3^{\prime}$ processing (Yanagisawa et al., 1993). The $5 \mathrm{~kb} T 1$ transcript is found in mast cells (Gächter et al., 1996), in subpopulations of cells in hematopoietic organs (embryonic liver, spleen, bone marrow) (Rößler et al., 1995) and the lung (Bergers et al., 1994) throughout ontogenesis. It encodes a 567 amino acid transmembrane protein (T1M) (Yanagisawa et al., 1993) which belongs to the interleukin 1 receptor (IL-IR) family (Yanagisawa et al., 1993; Mitcham et al., 1996; Parnet et al., 1996). The amino acid sequences of the ectodomain of $\mathrm{T} 1$ and the type I IL-1R are $28 \%$ identical and the intracellular portions share $40 \%$ identity. The genes encoding the two IL-1 receptors and $\mathrm{T} 1$ are tightly linked on mouse chromosome 1 (Tominaga et al., 1991) and human chromosome 2 (band 2q 12-13) (Sims et al., 1995). In addition, the intron/exon structures of the type I $I L-1 R$ and the $T 1$ gene are conserved, suggesting a common ancestor (Sims et al., 1995). T1M does not bind any of the IL1R ligands IL-1 $\alpha$, IL-1 $\beta$, or IL-1ra (Rößler et al., 1993; Danescu and Werenskiold, 1995; Kumar et al., 1995; Gayle et al., 1996). However, there is indirect evidence that it stimulates similar or identical signal transduction cascades as the IL-1R. Both, the type I IL-1R and a chimeric protein consisting of the extracellular domain of the IL-1R and the intracellular domain of $\mathrm{T} 1 \mathrm{M}$ are able to activate $\mathrm{NF} \kappa \mathrm{B}$, the MAP kinase $\mathrm{p} 38 /$ $\mathrm{RK}$, and transcription from the $I L-8$ promoter upon IL- $1 \alpha$ or IL-1 $\beta$ stimulation (Kumar et al., 1995; Reikerstorfer et al., 1995; Mitcham et al., 1996).

Recently, a 227 amino acid membrane bound putative T1 ligand was cloned from human and mouse (Gayle et al., 1996). Two additional soluble putative T1 ligands were partly purified and characterized as proteins of $32 \mathrm{kDa}$ and $18 \mathrm{kDa}$ (Kumar et al., 1995). While the membrane bound putative ligand was unable to activate $\mathrm{NF} \kappa \mathrm{B}$ and transcription from the $I L-8$ promoter upon binding to $\mathrm{T} 1 \mathrm{M}$ (Gayle et al., 1996), protein fractions containing the $32 \mathrm{kDa}$ and $18 \mathrm{kDa}$ putative soluble ligands were able to activate the p38/RK MAP kinase via T1M (Kumar et al., 1995).

The $2.7 \mathrm{~kb} T 1$ transcript was found in fibroblasts, the embryonic skin, in the retina and bones (Rößler et al., 1995), in developing mammary glands 3-4 weeks after birth as well as in experimental Ha-ras induced mammary tumors (Rößler et al., 1993). It encodes a 327 amino acid protein (T1S) which is N-glycosylated and secreted (Klemenz et al., 1989; Tominaga, 1989; Werenskiold, 1992; Takagi et al., 1993; Kalousek et al., 1994). Apart from nine amino acids at its carboxy 
terminus, T1S is identical to the extracellular domain of T1M (Yanagisawa et al., 1993). Soluble forms of type II IL-1R (Symons et al., 1995) as well as the related vaccinia virus B15R protein (Alcami and Smith, 1992; Spriggs et al., 1992) have previously been described and postulated to function as type I IL-1R antagonists.

Serum responsive genes have been divided into 'immediate early' and 'delayed early' genes based on the kinetics of their induction and the dependence on ongoing protein synthesis, the former being independent and the latter dependent on translation (Lau and Nathans, 1991). T1 mRNA accumulates in response to serum with a kinetics typical for delayed early gene transcripts peaking around $6-10 \mathrm{~h}$ after serum stimulation (Tominaga, 1989; Werenskiold et al., 1989). Delayed early genes are thought to be the targets of immediate early transcription factors. Indeed, we and others have demonstrated that the $T 1$ gene and its rat homologue fit-1 are induced in response to the expression of the immediate early serum response protein c-Fos and FosB (Bergers et al., 1994; Kalousek et al., 1994). Thus, it can be assumed that $\mathrm{T} 1$ gene induction in response to the mitogenic stimulation of quiescent cells is the consequence of cfos gene activation. Similarly, the onset of ras oncogene expression, as it is artificially achieved in conditional expression systems, is followed by the transient accumulation of c-Fos which in turn triggers the activation of the $T 1$ gene. However, sustained expression of oncogenic ras results in the downregulation of the c-fos and consequently of the $T 1$ gene (submitted for publication). This repression occurs in spite of permanent activation of the MAP kinases ERK-1 and ERK-2 and is the consequence of elevated AP-1 activity (unpublished observation).

The classification of the $T 1$ gene as an immediate- or delayed early serum responsive gene based on its serum inducibility in the presence of the protein synthesis inhibitor cycloheximide has been controversial. Three groups have described $T 1$ and fit-1 as delayed early genes based on the observation that the protein synthesis inhibitor cycloheximide blocked serum inducibility in Swiss 3T3 (Kalousek et al., 1994), $\mathrm{Balb} / \mathrm{c}$ 3T3 (Lanahan et al., 1992) and rat-1A cells (Bergers et al., 1994). In contrast, Yanagisawa et al., 1992 classified $T 1$ as an immediate early gene since cycloheximide in their experiments did not abolish the serum induction of $T 1$ in Balb/c 3T3 cells.

In this study we demonstrate that the $T 1$ gene is efficiently induced by the translation inhibitors cycloheximide and anisomycin in NIH3T3 but not in Swiss 3 T3 cells. The substance SB203580 (Cuenda et al., 1995), an inhibitor of the MAP kinases p38/RK and certain isoforms of JNK (Whitmarsh et al., 1997) blocked anisomycin mediated $T 1$ gene expression completely. This finding and the observation that u.v. does not result in $\mathrm{T} 1$ gene induction suggest that $\mathrm{p} 38 /$ $\mathrm{RK}$ is involved in the transmission of the anisomycin triggered signal to activate the $T 1$ gene.

The MAP kinase p38/RK (also known as CSBP and Mpk2) (Freshney et al., 1994; Lee et al., 1994; Rouse et al., 1994) is activated in mammalian cells in response to IL-1, TNF $\alpha$, and lipopolysaccaride and by stress signals (Han et al., 1994; Rouse et al., 1994; Cuenda et al., 1995; Raingeaud et al., 1995; Beyaert et al.,
1996). Its activator is the dual specificity kinase MKK6 (Raingeaud et al., 1996) which phosphorylates p38/RK at both threonine and tyrosine residues (Raingeaud et al., 1995). Once activated, it phosphorylates and thereby activates MAPKAP kinase-2 (Freshney et al., 1994; Rouse et al., 1994; Cuenda et al., 1995; Beyaert et al., 1996) and MAPKAP kinase-3 (Ludwig et al., 1996; McLaughlin et al., 1996) which in turn catalize the phosphorylation of the small heat shock protein Hsp25 (Freshney et al., 1994; Rouse et al., 1994; Cuenda et al., 1995; Beyaert et al., 1996; Ludwig et al., 1996; McLaughlin et al., 1996). p38/RK has been shown to phosphorylate the transcription factors ATF2 (Dérijard et al., 1995; Raingeaud et al., 1995, 1996), Elk-1 (Cano et al., 1995; Zinck et al., 1995; Raingeaud et al., 1996), and Max (Zervos et al., 1995) in vitro, however the in vivo activation of these transcription factors by $\mathrm{p} 38 / \mathrm{RK}$ has not yet been demonstrated. Here we show that anisomycin treatment resulted in the transcriptional activation of the $T 1$ gene. This response was observed using anisomycin concentrations which do not block translation as well as high concentrations which inhibit protein synthesis completely. Hence, the $T 1$ gene responds in an immediate early mode to the p38/RK signal transduction cascade stimulated by anisomycin while previous studies have shown that mitogenic stimuli, signaling through the MAP kinases of the ERK family, stimulate the $T 1$ gene in a delayed early manner. We further demonstrate that two physiological activators of the p38/RK pathway, IL-1 and TNF $\alpha$ also efficiently trigger T1 gene induction.

Serum and growth factor triggered $T 1$ gene induction is abrogated in ras transformed NIH3T3 cells. However, anisomycin, IL-1, and $\mathrm{TNF} \alpha$ mediated $T 1$ gene induction is not affected by the expression of the ras oncogene. p38/RK is not phosphorylated in unstimulated ras transformed NIH3T3 cells while the MAP kinases ERK-1 and ERK-2 are permanently in the phosphorylated, activated state. Thus, while the expression of a ras oncogene leads to the sustained activation of the ERK pathway and presumably through some feedback mechanism to $T 1$ gene downregulation, it does not affect the $\mathrm{p} 38 / \mathrm{RK}$ pathway and does not interfere with anisomycin, IL-1, and TNF $\alpha$ mediated $T 1$ gene induction.

\section{Results}

Two different pathways are used for the induction of $\mathrm{T} 1$ by serum and cycloheximide/anisomysin

We have previously reported that serum growth factors fail to induce the $T 1$ gene in Swiss $3 T 3$ fibroblasts if protein synthesis was blocked by the treatment of the cells with cycloheximide (Kalousek et al., 1994). However, we later observed that cycloheximide did not prevent $T 1$ mRNA accumulation in NIH3T3 cells, another murine fibroblastic cell line (Figure 1a). On first view this is in contradiction to our previous claim that $T 1$ is a delayed early serum responsive gene. However, cycloheximide is known to have pleiotropic effects; besides binding to ribosomes and thereby blocking translation it can also activate the JNK pathway (Kyriakis et al., 1994). Other protein synthesis 
a

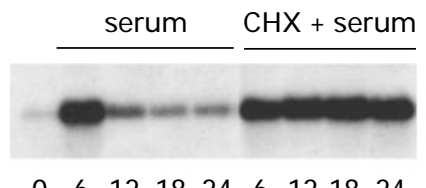

b

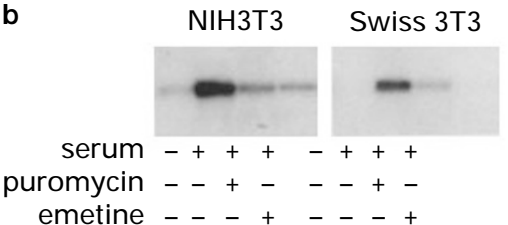
cycloheximide anisomycin serum

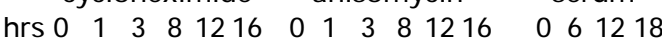
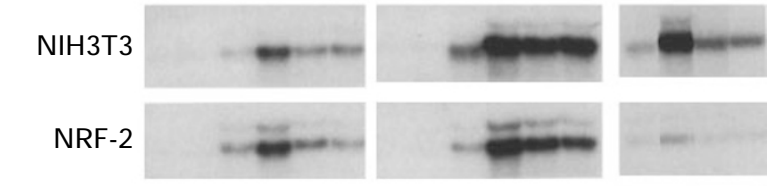

Swiss 3 T3

Balb/c 3T3
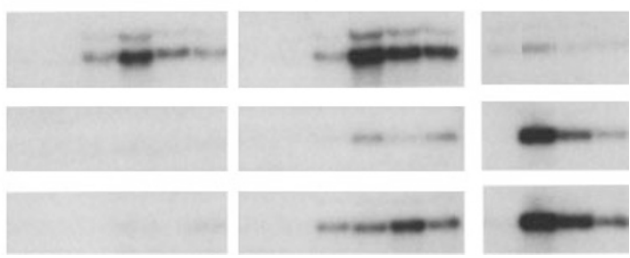

Figure 1 Accumulation of $T 1$ mRNA in response to serum and protein synthesis inhibitors. (a) Serum starved NIH3T3 cells were stimulated with $10 \%$ FCS in the presence or absence of $50 \mu \mathrm{g} / \mathrm{ml}$ cycloheximide. Total RNA was prepared before $(0)$ and after stimulation for the time periods (in hours) as indicated below the lanes. (b) Serum starved NIH3T3 and Swiss 3T3 cells were stimulated with $10 \%$ FCS in the presence or absence of $10 \mu \mathrm{g} / \mathrm{ml}$ puromycin or $10 \mu \mathrm{g} / \mathrm{ml}$ emetine for $6 \mathrm{~h}$. (c) Proliferating and serum starved NIH3T3, NFR-2, Swiss 3T3, and Balb/c 3T3 cells were treated with protein synthesis inhibitors (cycloheximide, $50 \mu \mathrm{g} / \mathrm{ml}$; anisomycin, $1 \mu \mathrm{g} / \mathrm{ml}$ ) or $10 \%$ FCS, respectively. RNA was collected after the time periods $(\mathrm{h})$ indicated above the lanes and $5 \mu \mathrm{g}$ of total RNA was subjected to Northern blot analysis using $T 1$ cDNA as the probe

inhibitors such as puromycin and emetine do not share this property with cycloheximide (Cano et al., 1994; Kyriakis et al., 1994) and were used to test whether serum growth factor mediated $T 1$ gene expression in NIH3T3 cells is also dependent on ongoing protein synthesis. As can be seen in Figure 1b, serum stimulation in the presence of either puromycin or emetine did not result in the accumulation of $T 1$ mRNA indicating that $T 1$ is indeed a delayed early serum responsive gene.

These findings suggest that cycloheximide treatment is sufficient to promote the accumulation of $T 1$ mRNA. Indeed, the addition of cycloheximide to NIH3T3 cells resulted in the synthesis of $T 1$ mRNA (Figure 1c). However, no $T 1$ mRNA accumulated under the same conditions in Swiss 3T3 cells which is in accordance with our previous finding (Kalousek et al., 1994). Anisomycin is another protein synthesis inhibitor which shares with cycloheximide the property of stimulating signal transduction pathways thereby triggering the expression of susceptible genes (Almendral et al., 1988; Quantin and Breathnach, 1988; Mahadevan and Edwards, 1991; Liang et al., 1996). Anisomycin treatment resulted in the accumulation of even higher levels of $T 1$ mRNA in all fibroblastic cell lines tested. In contrast to serum growth factors which induced the $T 1$ gene with similar efficiency in the different, non-transformed fibroblastic cell lines tested (Figure 1c), anisomycin treatment led to very high, intermediate and low levels of $T 1 \mathrm{mRNA}$ accumulation in NIH3T3, Balb/c 3T3 and Swiss 3T3 cells, respectively.

We have previously observed that serum-mediated T1 gene induction is attenuated in NIH3T3 cell lines which express the Ha-ras oncogene such as the NFR-2 cell line used in this study (Figure 1c). In contrast, we found that cycloheximide and anisomycin treatment led to similar levels of $T 1 \mathrm{mRNA}$ accumulation in normal and ras-transformed NIH3T3 cells (Figure 1c). This is a further indication that growth factors and cycloheximide/anisomycin operate through different signal transduction pathways.

\section{Anisomycin inducibility is not a general phenomenon among delayed early serum responsive genes}

We tested whether anisomycin treatment affects two other well studied delayed early serum responsive genes. For this experiment we used Balb/c 3T3 cells because the delayed early serum responsive genes encoding stromelysin and interstial collagenase are well induced by EGF, serum, and TPA in these but not in NIH3T3 cells. Balb/c 3T3 cells were rendered quiescent by serum deprivation and subsequently stimulated with EGF, serum, TPA and anisomycin. Serum- and TPA stimulation led to the well documented induction of the three tested delayed early serum responsive genes (reviewed in Aoyama and Klemenz, 1993). In contrast, anisomycin treatment resulted only in $T 1$ mRNA accumulation but did not stimulate stromelysin and collagenase gene transcription (Figure 2). This shows that the observed pattern of gene induction by mitogens and anisomycin is overlapping but not congruent.

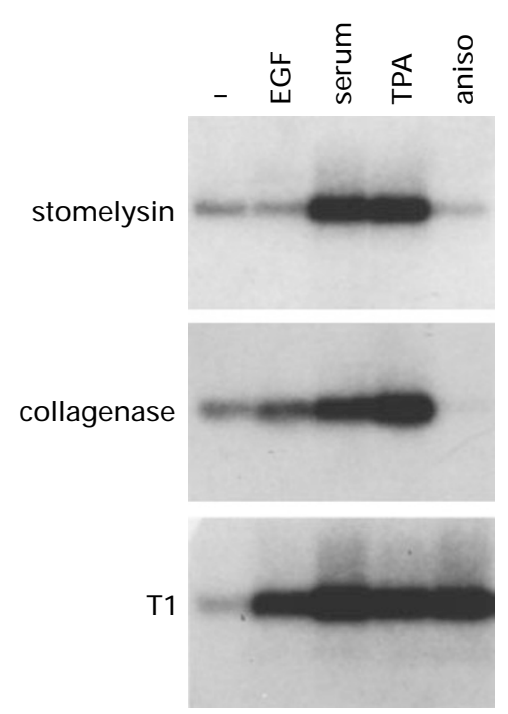

Figure 2 Anisomycin does not induce the delayed early serum responsive genes encoding stromelysin and interstitial collagenase. Serum starved Balb/c 3T3 cells were treated with $35 \mathrm{ng} / \mathrm{ml}$ epidermal growth factor (EGF), $10 \%$ FCS, $200 \mathrm{ng} / \mathrm{ml}$ 12-Otetradecanoylphorbol-13-acetate (TPA), or $1 \mu \mathrm{g} / \mathrm{ml}$ anisomycin (aniso) for $6 \mathrm{~h}$. Three identical Northern blots were prepared and hybridized with radioactive labeled probes recognizing stromelysin, collagenase and T1 mRNA 


\section{T1 is transcriptionally induced by anisomycin}

Different mechanisms can be envisaged for anisomycin mediated $T 1$ mRNA accumulation. Anisomycin affects cellular physiology in two ways. By virtue of binding to ribosomes it can block translation and by an unknown mechanism it can stimulate MAP kinase pathways. The two modes of operation exhibit different dose dependencies and can thus be distinguished. While protein synthesis is only inhibited at anisomycin concentrations above $40 \mathrm{ng} / \mathrm{ml}$ (Figure 3b) it turns on signal transduction pathways at lower concentrations (Mahadevan and Edwards, 1991). As can be seen in Figure $3 \mathrm{a}$, anisomycin led to the significant accumulation of the $2.7 \mathrm{~kb} T 1 \mathrm{mRNA}$ at concentrations which are insufficient to block protein synthesis and the maximal level of $T 1$ mRNA was reached at a concentration of $100 \mathrm{ng} / \mathrm{ml}$ which still allowed translation to proceed at ca. $40 \%$ of its efficiency in the absence of the drug.

Another mRNA which we fortuitously found to accumulate in response to anisomycin treatment of NIH3T3 cells encodes mouse tissue factor (Figure 3c). However, this response is only observed at anisomycin concentrations which are sufficiently high to block protein synthesis completely, i.e. approximately 30 times higher than the concentrations needed to achieve accumulation of $T 1 \mathrm{mRNA}$. We assume that the accumulation of tissue factor mRNA is the result of mRNA stabilization possibly due to the lack of the synthesis of a labile RNase.

This result suggests that transcriptional activation of the $T 1$ gene is the cause of or contributes to anisomycin-mediated $T 1$ mRNA accumulation. In order to test whether anisomycin does indeed trigger T1 gene transcription we performed nuclear run on assays. Nuclei were isolated from NIH3T3 cells which were serum starved for 1 day and exposed to serum or anisomycin for 2 and $3.5 \mathrm{~h}$, respectively. Radioactively labeled run on RNA was prepared and hybridized to Southern blots containing genomic and complementary T1 DNA (Figure 4). All DNA fragments containing transcribed portions of the $T 1$ gene hybridized to runon RNAs from anisomycin and serum stimulated but not from unstimulated cells. One genomic DNA fragment contains repetitive DNA. It scores positive in this hybridization experiment with all three different run-on probes and serves as an internal control for equal quality of the nuclear run-on transcripts and the DNA transfer. We conclude from this experiment that anisomycin treatment leads to $T 1$ gene expression and that the extent of transcription in response to serum and anisomycin is similar.

Using run on transcription assays we could show that anisomycin was also able to induce $T 1$ transcription in the ras transformed cell line NFR-2 (data not shown).

\section{A $\mathrm{T} 1$ reporter gene construct can be induced by ansiomycin}

Based on the finding that anisomycin stimulation leads to the transcriptional activation of the $T 1$ gene we investigated whether a $T 1$ reporter gene construct can be stimulated similarly. A plasmid (pFH6) was constructed which contains a CAT gene flanked by
$7.4 \mathrm{~kb}$ and $5 \mathrm{~kb}$ of the $T 1$ gene $5^{\prime}$ and $3^{\prime}$ flanking regions, respectively. It includes the first and part of the second as well as part of the eighth exon and was stably introduced into NIH3T3 cells (Figure 5). Since
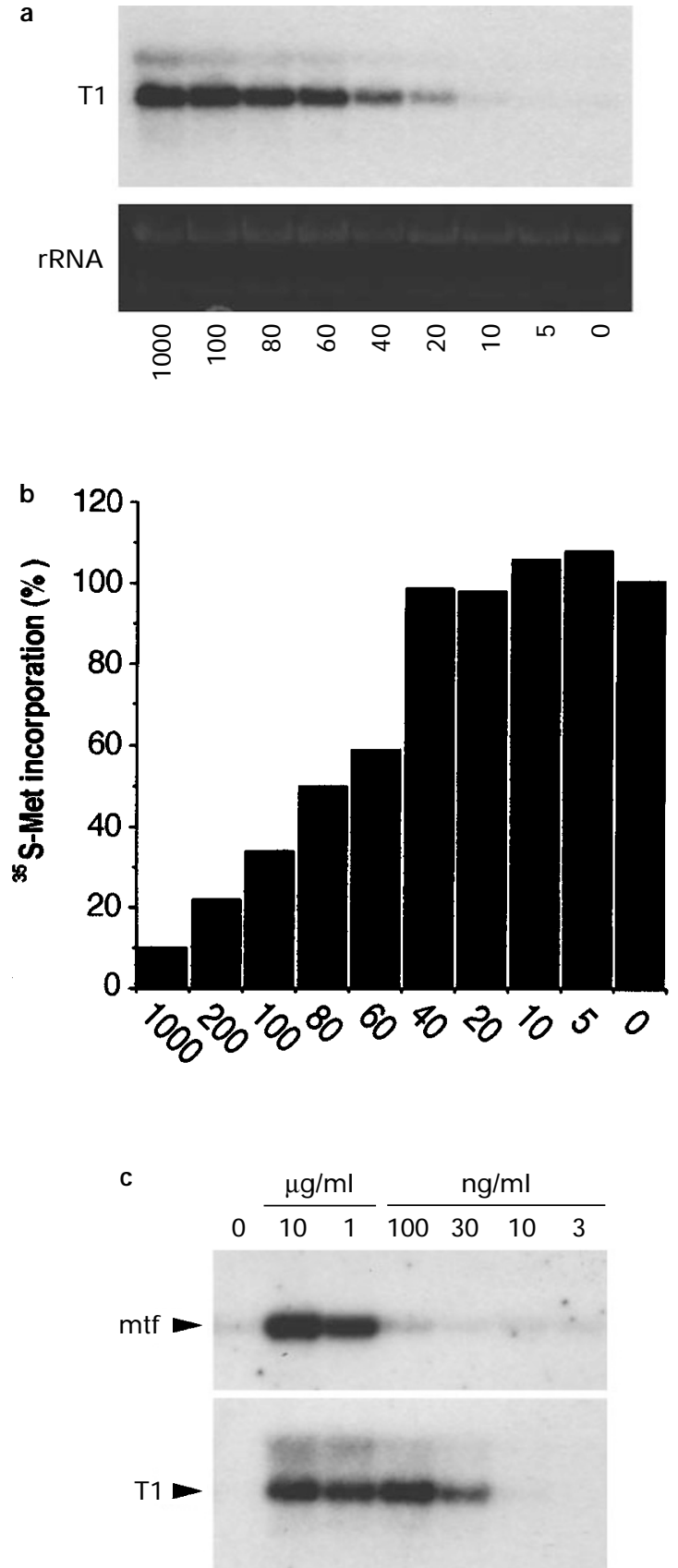

Figure $3 T 1$ is induced at concentrations of anisomycin which are subinhibitory for translation. Proliferating NFR-2 cells were treated with different concentrations of anisomycin $(\mathrm{ng} / \mathrm{ml})$ as indicated below the lanes. (a) Total RNA was collected $8 \mathrm{~h}$ after the addition of anisomycin and analysed by Northern blot with a T1-specific probe. The ethidium bromide stained gel is shown as a control for equal loading of RNA. The same result was obtained with non transformed NIH3T3 cells except that the amount of accumulated $5 \mathrm{~kb}$ T1 mRNA was always lower than in anisomycin treated NFR-2 cell. (b) Anisomycin was added to proliferating NFR-2 cells $30 \mathrm{~min}$ prior to the metabolic labeling of proteins with ${ }^{35} \mathrm{~S}$-methionine for $1 \mathrm{~h}$. TCA precipitable radioactivity was measured and the values corrected for total protein content. The value obtained for the cell culture which received no anisomycin was set to $100 \%$. (c) NIH3T3 cells were treated with anisomycin at the concentrations indicated above the lanes and RNA was isolated $6 \mathrm{~h}$ later. $5 \mu \mathrm{g}$ of total RNA was subjected to Northern blot analysis using a mouse tissue factor and a $T 1$ cDNA probe 


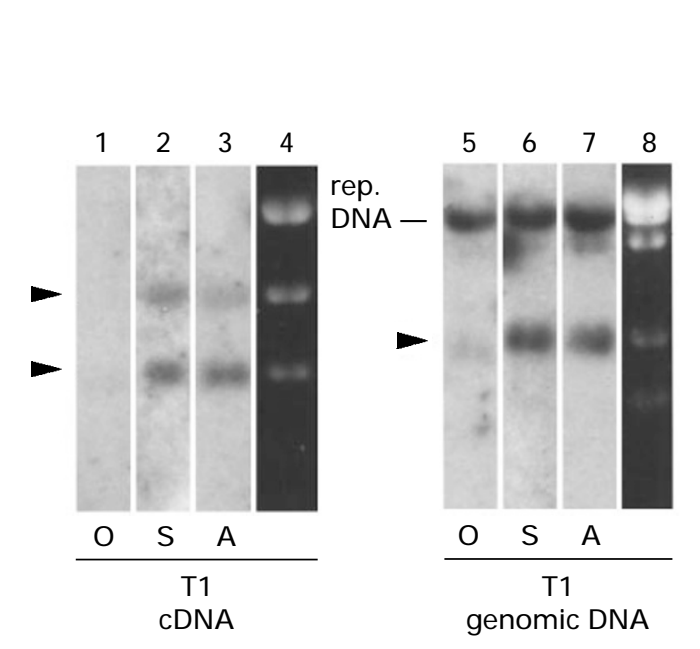

Figure $4 T 1$ is transcriptionally induced by anisomycin. Nuclei were prepared from serum starved NIH3T3 cells before (lanes 1 , 5) or 2 and $3.5 \mathrm{~h}$ after stimulation with $10 \% \mathrm{FCS}(\mathrm{S}$, lanes 2,6$)$ or $1 \mu \mathrm{g} / \mathrm{ml}$ anisomycin (A, lanes 3,7), respectively. Nuclear run on experiments were performed and the labeled run-on products hybridized to a Southern blot of restriction enzyme digested plasmid DNA. Left panel: $T 1$ cDNA; EcoRI digested pT1.10, giving rise to a $1 \mathrm{~kb}$ and a $1.6 \mathrm{~kb} \quad T 1$ cDNA fragment (arrowheads) and a $3.4 \mathrm{~kb}$ vector fragment. Right panel: T1 genomic DNA; pT1.28, restricted with EcoRI and PstI giving rise to a $1.2 \mathrm{~kb}$ DNA fragment from the transcribed portion of the gene (arrowhead). A genomic DNA fragment between $3.3 \mathrm{~kb}$ and $6.4 \mathrm{~kb}$ upstream of the transcription start site containing repetitive, transcribed sequences is indicated (rep. DNA). The ethidium bromide stained gels are shown in lanes 4 and 8 anisomycin blocks translation the cell clones could not be scored for CAT activity in response to anisomycin stimulation. Therefore we prepared total RNA of two transfected cell clones which were rendered quiescent by serum starvation and were either stimulated with serum or anisomycin for 4 and $8 \mathrm{~h}$. The RNA was subjected to Northern blot analysis using a CAT specific DNA probe (Figure 5). The same Northern blot was reprobed with a $T 1$ cDNA probe in order to monitor the induction of the endogenous $T 1$ gene. We found very efficient expression of the transfected gene in response to serum and anisomycin stimulation. The amount of CAT mRNA which accumulated in anisomycin treated cells was higher than in mitogenically stimulated cells. The ratio of accumulated CAT mRNA under the two conditions is similar to that of the endogenous $T 1$ gene.

The inhibitor of the MAP kinase p38/RK and some JNK isoforms, SB203580, interferes with anisomycin-mediated T1 gene induction

The p38/RK MAP kinase was recently shown to be essential for anisomycin induced glucose uptake into KB cells (Gould et al., 1995). This observation motivated us to test whether the p38/RK pathway is also involved in anisomycin-mediated $T 1$ gene induc-
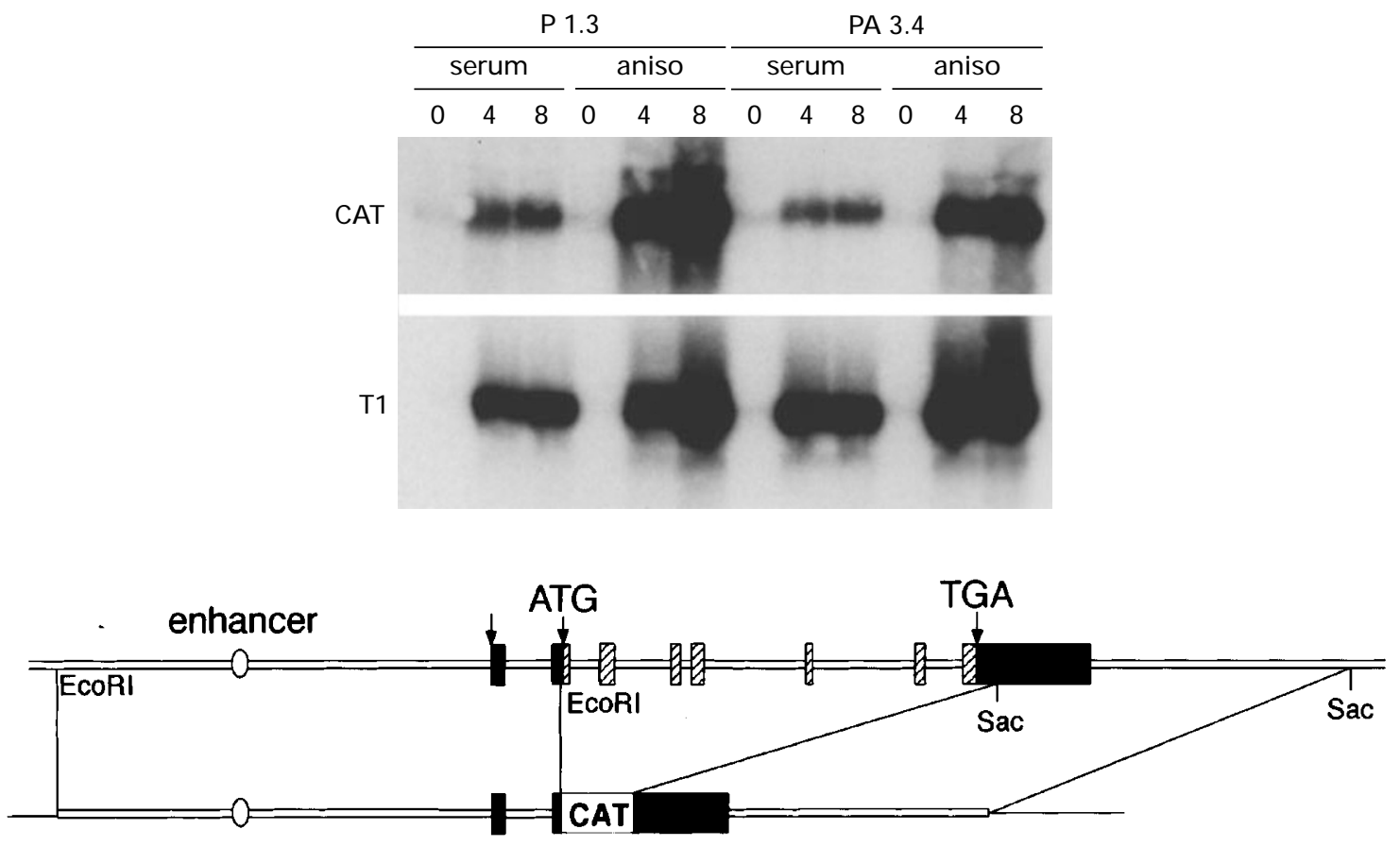

$1 \mathrm{~kb}$

Figure 5 A T1-CAT reporter gene is inducible by serum and anisomycin. The construct pFH6, shown in the lower part of the figure, was stably transfected into NIH3T3 cells. Two of the transfected cells clones, P1.3 and PA3.4, were rendered quiescent by serum starvation for $24 \mathrm{~h}$. Fresh medium containing $10 \%$ FCS or anisomycin at a final concentration of $100 \mathrm{ng} / \mathrm{ml}$ was added and RNA collected after 4 and $8 \mathrm{~h}$. The RNA was subjected to Northern blot analysis using in succession a $C A T$ and a $T 1$ specific probe to detect the exogenous and endogenous T1 transcripts, respectively. In the lower part of the figure the genomic organization of the T1 gene (upper part) and the pFH6 construct (lower part) are shown. pFH6 contains $7.4 \mathrm{~kb}$ and $5 \mathrm{~kb}$ of the $5^{\prime}$ and $3^{\prime}$ regions of the $T 1$ gene, respectively, including exon 1 and part of the exons 2 and 8 . The identification and characterization of the enhancer element has been described earlier (Trüb et al., 1994). Relevant cloning sites, the translational initiation and stop codons and the transcriptional start site which is used in fibroblasts are indicated. Filled and striped boxes represent non coding and coding regions of the $T 1$ transcript, respectively 
tion. To test this possibility we used the recently described inhibitor of p38/RK, SB203580 (Cuenda et al., 1995). Anisomycin-mediated T1 mRNA accumulation was blocked by SB203580 in a dose dependent manner and to completion at a concentration of $100 \mu \mathrm{M}$ (Figure 6). Run on transcription assays showed that the inhibitor SB203580 blocked anisomycin triggered T1 gene induction (data not shown). Initially SB203580 was described as a specific inhibitor of $\mathrm{p} 38 / \mathrm{RK}$. However, it was later reported that this substance can also inhibit most of the JNK isoforms at high, and the two isoformes $\mathrm{JNK} \beta 1$ and $\mathrm{JNK} \beta 2$ even at low concentrations (Whitmarsh et al., 1997). If anisomycin treatment led to $T 1$ gene induction via the stimulation of these JNK isoforms we expect to observe $T 1 \mathrm{mRNA}$ accumulation in response to u.v. irradiation. To test this possibility we subjected a NIH3T3 derived cell line which harbours a u.v. responsive TRE-CAT reporter gene to u.v. treatment. RNA was collected at different times following the irradiation and subjected to Northern blot analysis (Figure 7a). No increase in accumulated $T 1$ mRNA was observed at all time points examined and in response to three different doses of irradiation. As a control for the u.v. response we monitored the activation of the CAT reporter gene. CAT activity was induced following u.v. irradiation in a dose and time dependent manner (Figure 7b). u.v. treatment, in contrast to anisomycin treatment resulted in only very weak phosphorylation of p38/RK in the studied cell line as revealed from Western blot analysis using an antibody which selectively recognizes phosphorylated p38/RK (data not shown). These results suggest that anisomycin mediated $T 1$ gene expression is not the consequence of $\mathrm{JNK}$ but rather of $\mathrm{p} 38 / \mathrm{RK}$ activation.

\section{Anisomycin leads to $\mathrm{p} 38 / \mathrm{RK}$ activation}

To further substantiate the finding that anisomycin triggers p38/RK activation we investigated whether $\mathrm{p} 38 / \mathrm{RK}$ becomes phosphorylated in response to

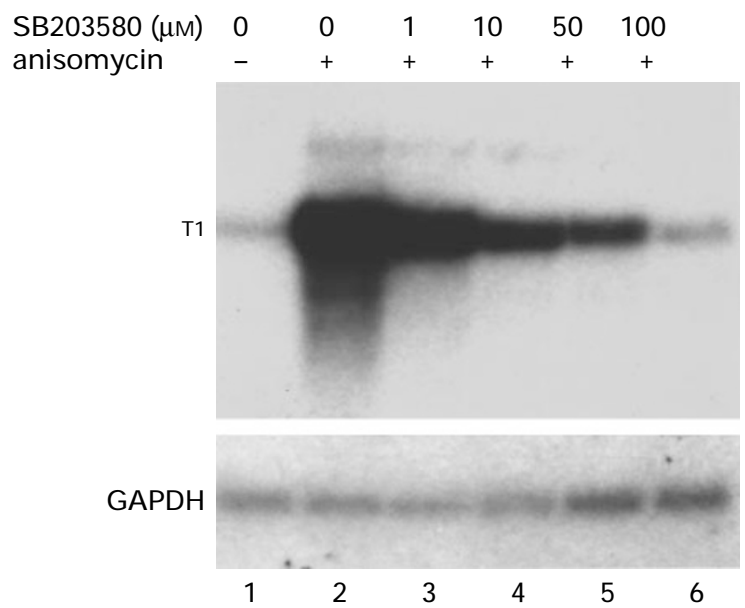

Figure 6 The p38/RK inhibitor SB203580 blocked T1 gene induction by anisomycin. Growth arrested NIH3T3 cells were pretreated with the indicated concentrations of SB203580 for $15 \mathrm{~min}$ prior to the addition of $1 \mu \mathrm{g} / \mathrm{ml}$ anisomycin. $6 \mathrm{~h}$ later total RNA was prepared and subjected to Northern blot analysis with a T1-specific probe (top). The same blot was reprobed with a $G A P D H$-specific probe to control for equal loading and the integrity of the RNA (bottom)
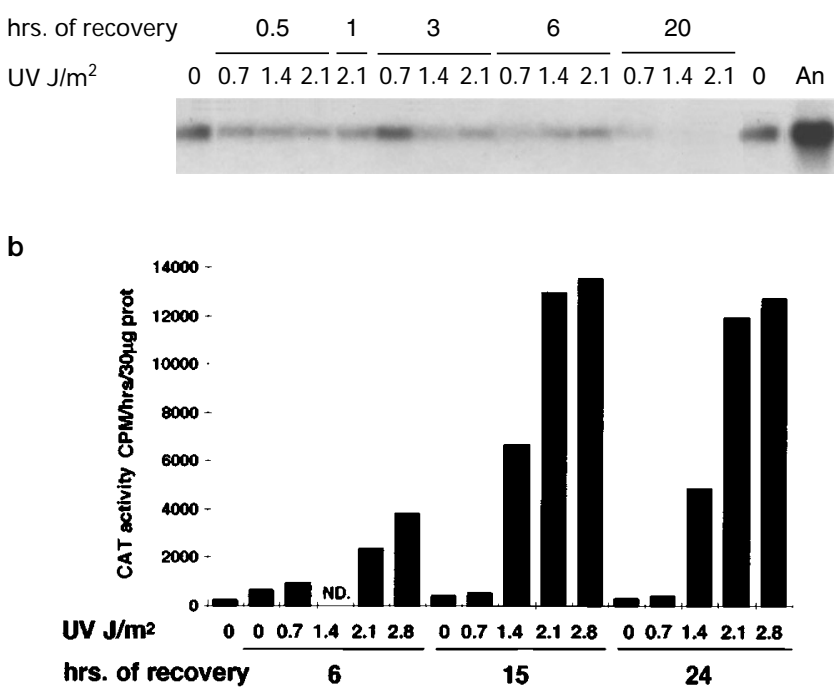

Figure 7 u.v. irradiation did not induce T1 mRNA accumulation. CT-7 cells (a NIH3T3 derived cell line which is stably transfected with the u.v.-inducible reporter construct $5 \times$ TRETATA-CAT) were irradiated with u.v. doses of $0.7,1.4,2.1$, and $2.8 \mathrm{~J} / \mathrm{m}^{2}$. After irradiation, the cells were allowed to recover for the time periods indicated. In parallel, NIH3T3 cells were treated with $1 \mu \mathrm{g} / \mathrm{ml}$ anisomycin for $6 \mathrm{~h}$. (a) Total RNA was harvested and subjected to Northern blot analysis using a $T 1$ specific probe. (b) Protein extracts were prepared and CAT activity measured in lysates normalized for protein content

anisomycin treatment. NIH3T3 cells were serum starved for $24 \mathrm{~h}$ and exposed to either emetin, cycloheximide, anisomycin or serum. Only cycloheximide and anisomycin led to p38/RK phosphorylation as revealed by Western blot analysis using an antibody which selectively recognizes the phosphorylated form of p38/RK (Figure 8a). A parallel Western blot was reacted with an anti $\mathrm{p} 38 / \mathrm{RK}$ antibody which does not discriminate between the phosphorylated and the unphosphorylated form to demonstrate that equal amounts of p38/RK are present in all extracts (Figure $8 b)$.

In several ras transformed fibroblasts the MAP kinases ERK-1 and ERK-2 were found to be permanently phosphorylated (Leevers and Marshall, 1992; Minden et al., 1994). We investigated whether the Ras oncoprotein affects p38/RK similarly. The basal level of phosphorylated $\mathrm{p} 38 / \mathrm{RK}$ in ras transformed NFR-2 cells was low, comparable to that in normal NIH3T3 cells. Anisomycin treatment resulted in the rapid and strong phosphorylation of p38/RK (Figure $8 \mathrm{a}, \mathrm{b})$. Thus, ras transformation does not influence basal and anisomycin mediated p38/RK phosphorylation.

One of the targets of p38/RK is MAP kinase activated protein kinase-2 (MAPKAPK-2) which upon activation phosphorylates the small heat shock protein Hsp25 (Freshney et al., 1994; Rouse et al., 1994; Cuenda et al., 1995). Hence, anisomycin treatment should lead to Hsp25 phosphorylation. There are two major phosphorylation sites on murine Hsp25. Unphosphorylated, mono- and diphosphorylated Hsp25 have distinct migration properties on $2 \mathrm{D}$ gels and give rise to the spots a, b, and c, respectively as indicated in Figure 8c. Fibroblasts are devoid of Hsp25 under normal conditions (Aoyama et al., 1993; Klemenz et 
a
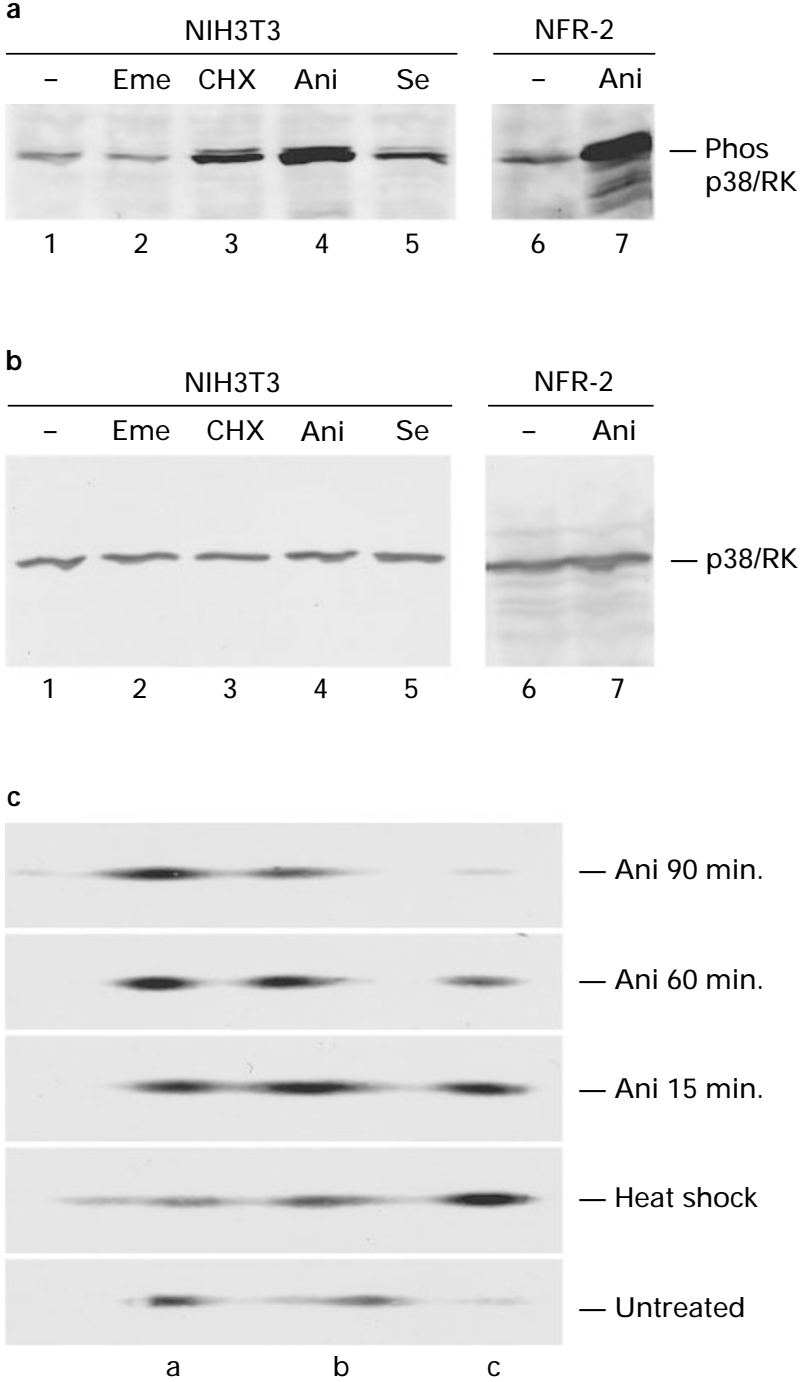

Figure 8 Anisomycin treatment led to the phosphorylation of the MAP kinase p38/RK. (a) Serum starved NIH3T3 and NFR-2 cells were incubated with $10 \mu \mathrm{g} / \mathrm{ml}$ emetine (Eme), $50 \mu \mathrm{g} / \mathrm{ml}$ cycloheximide (CHX), $1 \mu \mathrm{g} / \mathrm{ml}$ anisomycin (Ani) or $10 \%$ FCS (Se) for $15 \mathrm{~min}$. Total cellular proteins were separated on a $12.5 \%$ SDS polyacrylamide gel and subjected to Western blot analysis with an antibody directed selectively against p38/RK which is phosphorylated at Y182. (b) An identical Western blot was developed with a p38/RK specific antibody which does not discriminate between the phosphorylated and the unphosphorylated form of $\mathrm{p} 38 / \mathrm{RK}$. (c) $\mathrm{C} 2 \mathrm{C} 12$ myoblasts were either incubated at $44^{\circ} \mathrm{C}$ for $20 \mathrm{~min}$ (heat shock), treated with $1 \mu \mathrm{g} / \mathrm{ml}$ anisomycin for 15,60 and $90 \mathrm{~min}$ or left untreated. Cellular proteins were subjected to 2-dimensional Western blot analysis with an antibody directed against Hsp25. The unphosphorylated and the mono- and diphosphorylated forms of Hsp25 are marked a, b, and $\mathrm{c}$, respectively

al., 1993). Several stress conditions such as hyperthermia result in both, Hsp25 synthesis and phosphorylation which make it difficult to test anisomycin-mediated Hsp25 phosphorylation in these cells. We therefore chose to use the myoblast cell line $\mathrm{C} 2 \mathrm{C} 12$ which contains high amounts of Hsp25 under normal conditions. Anisomycin treatment led to the rapid and transient phosphorylation of $\mathrm{Hsp} 25$ as revealed from the substantial increase in the abundance of spot $\mathrm{c}$ in Figure 8c. The extent of phosphorylation is similar to that seen after a heat shock (Crête and Landry,
1990). This is consistent with the notion that anisomycin leads to the activation of the p38/RKMAPKAPK-2-Hsp25 cascade.

\section{$\mathrm{T} 1$ gene expression is induced in response to $I L-1$ and $T N F \alpha$}

Two well studied physiological activators of the p38/ RK signalling cascade are the proinflammatory cytokines IL-1 and TNFa (Freshney et al., 1994; Geng et al., 1996; Raingeaud et al., 1995; Modur et al., 1996; Nahas et al., 1996; Beyaert et al., 1996). Since fibroblasts express receptors for both ligands we expected to observe $T 1$ gene induction in IL-1 and TNF $\alpha$ stimulated NIH3T3 cells. Indeed, IL-1 and $\mathrm{TNF} \alpha$ treatment led to $T 1$ mRNA accumulation in NIH3T3 cells with similar kinetics as was observed following serum stimulation (Figure 9). Likewise, TI mRNA accumulated in response to IL- 1 and TNF $\alpha$ in the ras transformed NFR-2 cell line. These cells do not express the $T 1$ gene in response to the stimulation with serum (Figures 1c, 9a), TPA, PDGF, FGF, and LPA (Kessler et al., submitted). Thus, those agents which stimulate $T 1$ gene expression via the activation of a stress activated MAP kinase pathway (IL-1, TNF $\alpha$, anisomycin) can stimulate $T 1$ gene expression irrespective of ras transformation, whereas activators of the ERK pathway (TPA, serum, LPA, PDGF, and FGF) can stimulate $T 1$ gene expression only in the nontransformed cells.
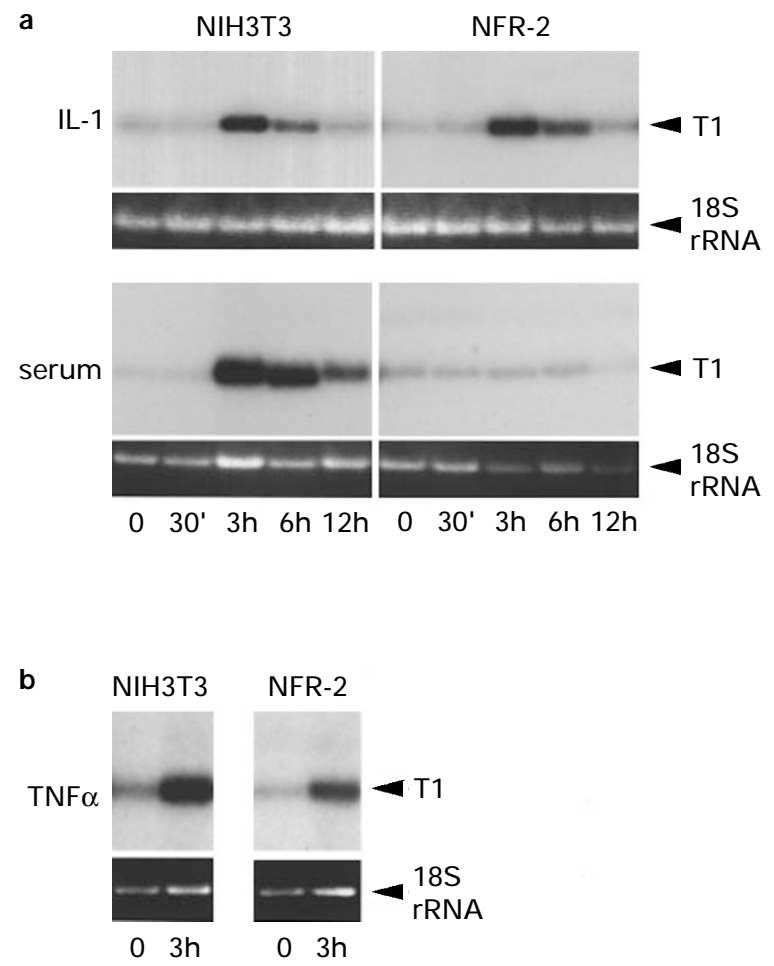

Figure $9 T 1$ mRNA accumulates in response to IL-1 and TNF $\alpha$ treatment. (a) Proliferating NIH3T3 and NFR-2 cells were stimulated with $20 \mathrm{ng} / \mathrm{ml} \mathrm{IL-1} \mathrm{and} \mathrm{serum} \mathrm{starved} \mathrm{cells} \mathrm{with}$ $10 \%$ FCS for the indicated times. (b) Quiescent NIH3T3 and NFR-2 cells were stimulated with $20 \mathrm{ng} / \mathrm{ml} \mathrm{TNF} \alpha$ for $3 \mathrm{~h}$. RNA was harvested and subjected to Northern blot analysis using a T1 specific probe 
p38/RK activation is insufficient to induce the T1 gene in Swiss $3 T 3$ cells

As shown previously, treatment of Swiss 3T3 cells with cycloheximide did not result in $T 1$ mRNA accumulation at all concentrations tested and anisomycin had only a very weak inducing effect (Figure 1c). Since we have shown that $\mathrm{p} 38 / \mathrm{RK}$ activation is required for anisomycin-mediated $T 1$ gene induction we tested whether either the amount of $\mathrm{p} 38 / \mathrm{RK}$ or its phosphorylation state in response to anisomycin differs between NIH3T3 and Swiss 3T3 cells. As shown in Figure 10, both the total amount of p38/ RK as well as the extent of its phosphorylation after anisomycin addition are comparable in the two cell lines as revealed by Western blot analysis.

Anisomycin treatment also led to the accumulation of c-fos mRNA in NIH3T3 cells (Figure 11a). Similar amounts of c-fos mRNA were found if cells were treated with low concentrations of anisomycin (30 ng/ $\mathrm{ml}$ ) which hardly inhibited translation and at a high concentration $(1 \mu \mathrm{g} / \mathrm{ml})$ which blocked translation efficiently (Figure 11a). Hence, we assume that c-fos mRNA accumulation in NIH3T3 cells is the consequence of transcriptional induction as has been shown previously in $\mathrm{C} 3 \mathrm{H}$ 10T1/2 cells (Mahadevan and Edwards, 1991). Following anisomycin addition, Swiss $3 \mathrm{~T} 3$ cells accumulated c-fos mRNA to levels which even exceeded those in NIH3T3 cells. Again, this effect was similar if cells were treated with low or high concentrations of anisomycin and is therefore probably due to transcriptional stimulation. The anisomysin mediated c-fos mRNA synthesis could be inhibited with SB203580, indicating that $\mathrm{p} 38 / \mathrm{RK}$ is involved in the induction. (Figure 11a, lane 10). This experiment revealed that Swiss $3 \mathrm{~T} 3$ cells are not refractory to anisomycin mediated gene induction and that anisomycin stimulated activation of the c-fos gene apparently needs an additional signal which is weak in NIH3T3 and strong in Swiss 3T3 cells.

We have shown above that $T 1$ mRNA accumulates to a similar extent in NIH3T3 and NFR-2 cells in response to anisomycin stimulation (Figure 1c). In contrast, anisomycin mediated c-fos mRNA accumulation is severly repressed in NFR-2 cells. (Figure 11b). This is reminescent of serum stimulated $T 1$ gene

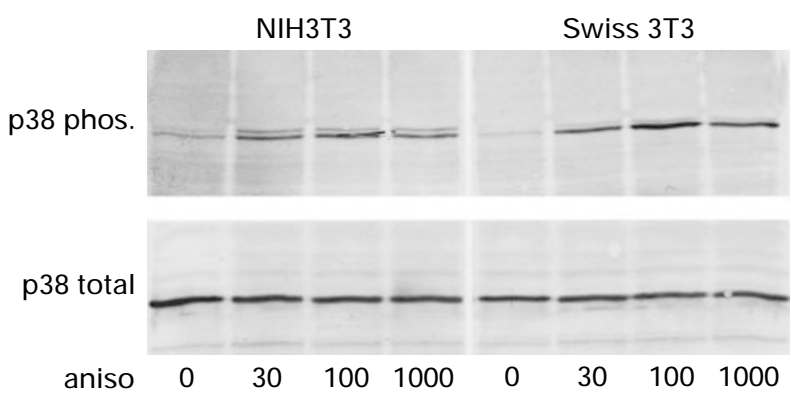

Figure 10 The amount of $\mathrm{p} 38 / \mathrm{RK}$ and the extent of its phosphorylation in response to anisomycin is comparable in NIH3T3 and Swiss 3T3 cells. NIH3T3 and Swiss 3T3 cells were treated with the doses of anisomycin $(\mathrm{ng} / \mathrm{ml})$ indicated below the lanes. After $15 \mathrm{~min}$, total cellular protein extracts were prepared and analysed on two identical Western blots developed with antibodies directed against either Y182 phosphorylated or total p38/RK induction which is only observed in normal but not in ras transformed fibroblasts. These results indicate that anisomycin mediated induction of the T1 and the c-fos genes operate through different mechanisms.

\section{Discussion}

This study was carried out to clarify an apparent contradiction in the classification of $T 1$ as an immediate early or delayed early mitogen responsive gene. It has led us to the finding that the $T 1$ gene can be induced through two different signal transduction cascades, the ERK and the p38/RK pathways. The stimulation of the ERK pathway by mitogens such as serum, LPA and PDGF leads to the phosphorylation of transcription factors which are involved in the stimulation of immediate early genes (Moolenaar, 1994; Hill and Treisman, 1995). We have previously shown that $T 1$ gene expression in response to serum

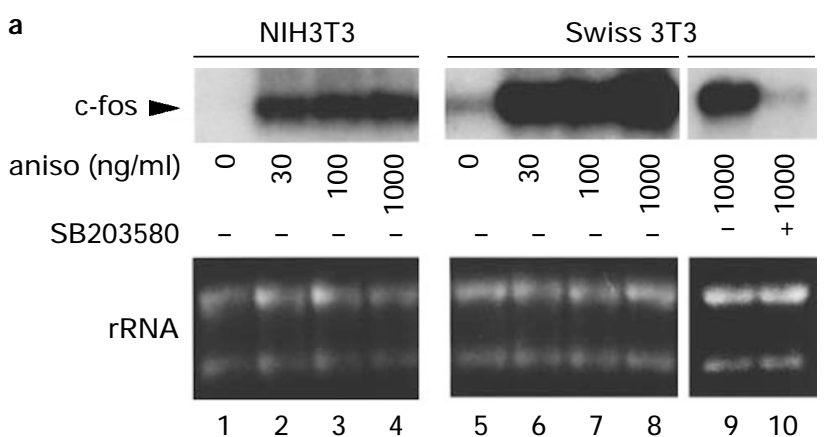

b

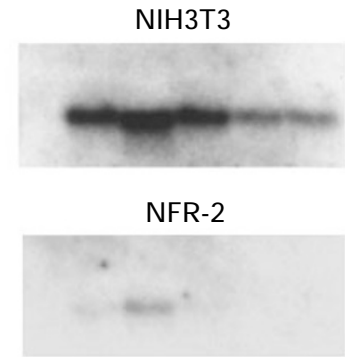

Swiss $3 T 3$

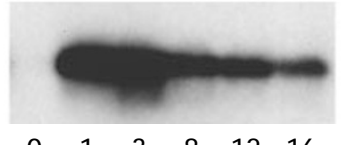

time (h) $\quad \begin{array}{llllll}0 & 1 & 3 & 8 & 12 & 16\end{array}$

Figure 11 c-fos mRNA accumulated in response to anisomycin in both, NIH3T3 and Swiss 3T3 but not in NFR-2 cells. (a) NIH3T3 and Swiss 3T3 were incubated with anisomycin at concentrations which blocked translation only partially (30 and $100 \mathrm{ng} / \mathrm{ml})$ or completely $(1 \mu \mathrm{g} / \mathrm{ml})$. A Northern blot was prepared with total RNA isolated before and $1 \mathrm{~h}$ after anisomycin treatment and hybridized with a c-fos specific probe. In a separate experiment Swiss $3 \mathrm{~T} 3$ cells were treated with the p38/RK inhibitor SB $203580(+)$ or not $(-)$ prior to the stimulation with $1 \mu \mathrm{g} / \mathrm{ml}$ anisomycin for $1 \mathrm{~h}$. All RNA samples except those in lanes 9 and 10 were analysed on the same Northern blot. The ethidium bromide stained gels are shown as a control for equal loading of RNA. (b) NIH3T3, NFR-2, and Swiss $3 \mathrm{~T} 3$ cells were treated with $100 \mathrm{ng} / \mathrm{ml}$ anisomycin for the time periods indicated below the lanes. RNA was prepared and analysed on the same Northern blot which was developed with a c-fos specific DNA probe 

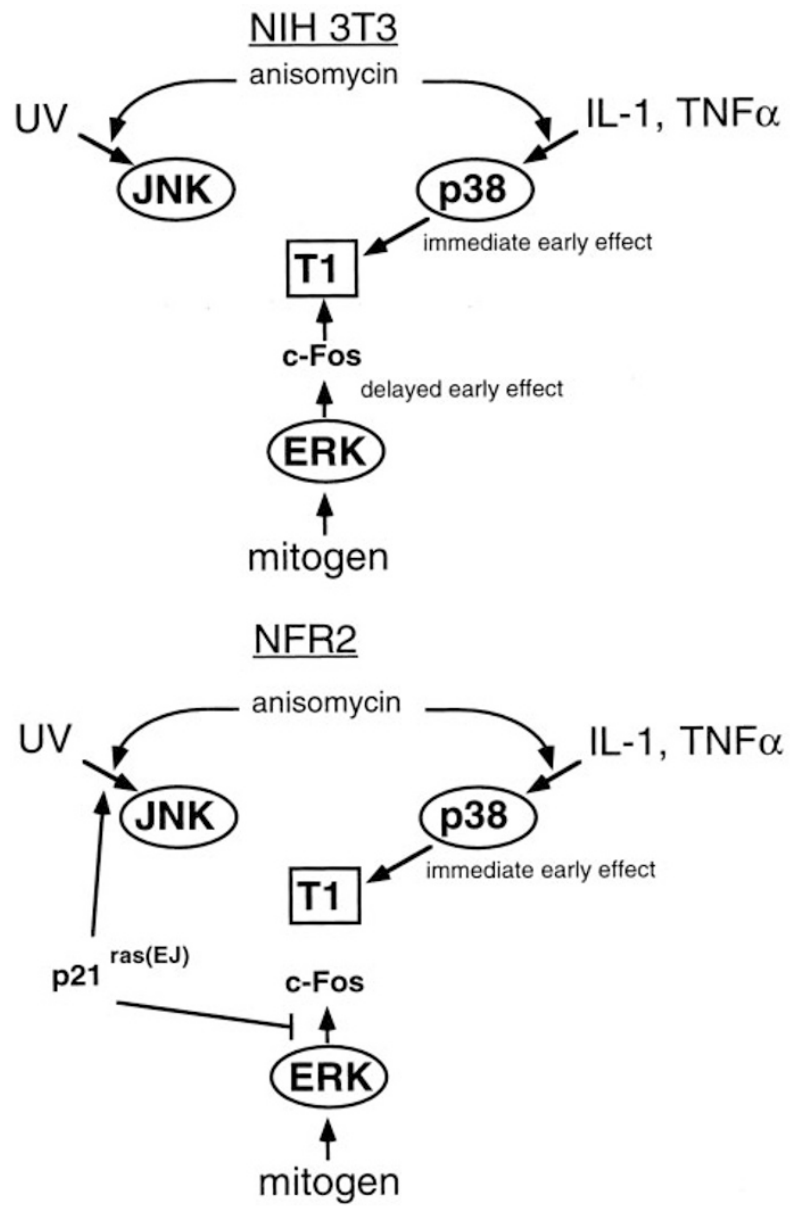

Figure 12 Model for the induction of the $T 1$ gene in response to mitogenic stimulation and anisomycin, IL-1, and TNF $\alpha$ treatment in normal NIH3T3 and ras transformed NFR-2 cells. In normal NIH3T3 fibroblasts the $T 1$ gene can be induced through the stimulation of the p38/RK and the ERK pathway, the former being an immediate early and the latter a delayed early effect, as defined by the requirement for ongoing protein synthesis. In the ras transformed NFR-2 cells c-fos gene induction is blocked and consequently no $T 1$ gene expression in response to mitogenic stimulation is observed. However, p38/RK mediated T1 gene activation is not affected in these cells

stimulation requires the transcription factor c-Fos (Kalousek et al., 1994, Trüb et al., 1994). c-Fos levels are very low in quiescent cells but increase drastically and transiently during the early phase of cell cycle entry (Lau and Nathans, 1991). If the synthesis of cFos is blocked, no $T 1$ gene induction ensues which categorizes $T 1$ as a delayed early gene (Figure 12). This classification holds true despite the finding that cycloheximide treatment of NIH3T3 cells does not preclude $T 1$ gene expression in response to mitogenic stimulation because we have shown that puromycin and emetine which inhibit translation without stimulating signal transduction cascades block serum mediated T1 gene expression in all three fibroblastic cell lines studied. We provided evidence that the second signalling pathway which results in $T 1$ gene expression is the $\mathrm{p} 38 / \mathrm{RK}$ cascade.

Pretreatment of cells with low concentrations of SB203580 causes the inhibition of p38/RK (Cuenda et al., 1995) and certain JNK isoforms (Whitmarsh et al., 1997) and prevented anisomycin mediated $T 1$ gene expression. Since u.v. irradiation did not result in T1 gene activation and did not cause substantial phosphorylation of $\mathrm{p} 38 / \mathrm{RK}$ we conclude that anisomycin acts through the activation of the p38/RK pathway to stimulate $T 1$ gene activation. This is in accordance with the observation that anisomycin stimulated $T I$ gene expression is not affected in ras transformed fibroblasts. ras oncogene expression results in the permanent activation of JNK and ERK but not p38/RK. Sustained activation of a signal transduction pathway should result either in the permanent stimulation of target gene expression or in gene silencing if a feedback inhibitory loop is involved.

The ability of anisomycin to stimulate the p38/RK pathway was further supported by the finding that anisomycin treatment resulted in the phosphorylation of p38/RK and Hsp25. The latter is a substrate of MAPKAPK-2, a downstream target of p38/RK (Freshney et al., 1994; Rouse et al., 1994; Cuenda et al., 1995). This is in concordance with recent observations of anisomycin mediated activation of p38/RK in KB (Gould et al., 1995) and 293 cells (Brunet and Pouysségur, 1996).

Anisomycin caused $T 1$ gene induction over a wide range of concentrations. The highest concentrations used in this study inhibited protein synthesis efficiently. The transcription factors mediating $T 1$ gene induction under these conditions must have been present before the onset of the stimulation with anisomycin. By this criterion $T 1$ has to be classified as a immediate early gene, not requiring de novo synthesis of the transcriptional stimulators. This is unlike the mechanism operating in response to growth factor mediated $T 1$ gene induction. Mitogenic stimulation leads to the synthesis of immediate early gene products which are involved in $T 1$ gene activation.

Anisomycin can probably cause the accumulation of specific mRNAs through different mechanisms. By virtue of its activity as a stimulator of signal transduction cascades it can cause the direct transcriptional activation of some genes such as the $T 1$ gene. By virtue of its ability to inhibit translation it might cause the loss of labile transcriptional repressors or RNases and thereby induce transcription in an indirect manner or cause mRNA stabilization, respectively. The accumulation of tissue factor mRNA might be the result of such a mechanism as it is only observed under conditions of complete protein synthesis inhibition. TI is one of the few genes for which transcriptional induction in response to the activation of the p38/RK pathway has been demonstrated. Such genes are the true targets of the $\mathrm{p} 38 / \mathrm{RK}$ signal transduction cascade and the study of the mechanisms of their transcriptional induction should lead to the identification of the transcription factors which are the nuclear targets of this signalling pathway.

We have observed that the c-fos gene is induced during the onset of ras oncogene expression but that it is silenced upon the prolonged presence of oncogenic $\mathrm{p} 21^{\text {ras }}$. There is evidence that this is the consequence of sustained fra-1 gene expression and the activation of cJun through its N-terminal phosphorylation by JNK. The Fra-1/c-Jun heterodimeric AP-1 complex which predominates in ras transformed NIH3T3 cells and which is present in high amounts throughout the cell cycle is an efficient repressor of the c-fos gene (manuscript submitted). The lack of c-fos gene 
induction in ras transformed cells is the likely cause for the unresponsiveness of the $T 1$ gene to mitogen mediated activation in these cells. However, as we have shown here, $T 1$ gene induction occurs in response to anisomycin, IL-1, and $\mathrm{TNF} \alpha$ in normal and ras transformed NIH3T3 cells alike (Figure 12). This is a further indication that different transcription factors mediate the activation of the $T 1$ gene in response to the stimulation of the p38/RK and ERK1/ERK2 pathways and in particular that c-Fos is only involved in the latter response.

The extent of anisomycin mediated gene induction varies strongly among different murine fibroblastic cell lines. While the $T 1$ gene is induced with high, intermediate, and low efficiency in NIH3T3, Balb/c 3T3, and Swiss 3T3 cells, respectively, the inverse is true for the c-fos gene. The presence of different amounts of $\mathrm{p} 38 / \mathrm{RK}$ in these cell lines or its differential susceptibility to phosphorylation in response to anisomycin could be excluded as possible explanations. We assume that different downstream target molecules of the p38/RK pathway are involved in the activation of the $T 1$ and the c-fos gene and that these molecules are present in different amounts in the tested cell lines. Alternatively, other transcription factors which cooperate with the p38/RK target molecules in gene activation might be the limiting components and accumulate to different levels in the studied cell lines. Currently only two in vivo substrates of $\mathrm{p} 38 / \mathrm{RK}$ are known, the related MAPKAP kinase-2 (Cuenda et al., 1995) and MAPKAP kinase-3 (Ludwig et al., 1996; McLaughlin et al., 1996). Their only known substrate is the small heat shock protein Hsp25, an unlikely candidate for gene activation. The MAPKAP kinase-3 is a target of stress and mitogen stimulated MAP kinase pathways. It is interesting to note that its activation is transient in response to mitogenic stimulation and sustained in response to stress (Ludwig et al., 1996). Similarly, the $T 1$ gene is induced for only a short time following cell cycle entry of quiescent cells, but its expression is prolonged in the presence of anisomycin. These kinetic considerations make the substrates of MAPKAP kinase- 3 appear as good candidates for $T 1$ gene stimulators. We have shown in this report that a $T 1$ gene construct can be induced by anisomycin treatment in NIH3T3 cells. Promoter dissection studies should lead us to the identification of the crucial DNA sequence motives involved in anisomycin mediated $T 1$ gene activation. The transcription factors interacting with such sequence motives are expected to be the critical targets of the p38/RK signal transduction pathway. Thus, the $T 1$ gene is a very useful tool to investigate the p38/RK pathway.

It is interesting to note that the stimulation of a hybrid protein consisting of the extracellular domain from the IL-1 receptor and the intracellular domain of T1 leads to the activation of the p38/RK pathway (Kumar et al., 1995). We speculate that the activation of the membrane anchored form of $\mathrm{T} 1$ may result in enhanced $T 1$ gene induction. An autoregulatory inhibition or stimulation of the $T 1$ response might ensue, depending of whether the synthesis of the secreted or the membranous form of $\mathrm{T} 1$ occurs.

The membrane anchored form of $\mathrm{T} 1$ is predominantly found on the surface of mast cells. These cells store $\mathrm{TNF} \alpha$ in cytoplasmatic granules. Upon antigenic stimulation they release $\mathrm{TNF} \alpha$ and start to produce several cytokines including IL-1. Secreted TNF $\alpha$ and IL-1 might stimulate $T 1$ gene expression in neighbouring cells resulting in the synthesis and secretion of the soluble T1 protein. Assuming that the soluble form of T1 can bind the putative T1 ligand with similar affinity as the membranous form this could lead to the quenching of the $\mathrm{T} 1$ response. The recently described putative T1 ligand will be a useful tool to study this model.

\section{Materials and methods}

\section{Cell cultures}

The murine fibroblastic cell lines NIH3T3, Swiss 3T3, Balb/c 3T3 (clone A31), the Ha-ras (EJ) transfected clone NFR-2 (Aoyama et al., 1993), and the myoblast cell line C2C12, were grown in Dulbecco's modified Eagle's medium (DMEM) (Life Technologies Inc.) supplemented with $10 \%$ fetal calf serum (FCS), penicillin (100 units $/ \mathrm{ml}$ ) and streptomycin $(100 \mathrm{mg} / \mathrm{ml})$. Cell proliferation was arrested by reducing the FCS concentration to $0.5 \%$ for $24 \mathrm{~h}$. Recombinant mouse IL- $1 \beta$ and TNF $\alpha$ were purchased from Genzyme Diagnostics (Cambridge, MA) and Sigma, respectively, and used at $20 \mathrm{ng} / \mathrm{ml}$.

To measure the inhibitory effect of anisomycin, NFR-2 cells were incubated with anisomycin which was dissolved in $50 \%$ ethanol or with the solvent only for $30 \mathrm{~min}$. Thereafter, cells were metabolically labelled with ${ }^{35} \mathrm{~S}$-methionine for $1 \mathrm{~h}$, extensively washed, lysed in a hypotonic buffer $(10 \mathrm{mM}$ Tris$\mathrm{HCl}, \mathrm{pH}$ 8.0, 0.1 mM DTT, $1 \mathrm{mM}$ PMSF) and proteins were precipitated with trichloroacetic acid (TCA). The protein pellet was dissolved in the sample buffer for SDS polyacrylamide gels and aliquots were spotted onto two nitro-cellulose filters. One filter was stained with amido black and protein concentrations were determined according to Schaffner and Weissman (Schaffner and Weissman, 1973). The other filter was used to measure radioactivity. The amount of incorporated radioactivity was normalised for equal amount of protein.

\section{u.v. irradiation}

For u.v. irradiation of cells the medium was removed and the cells were irradiated in a Stratalinker 1800 u.v. Crosslinker (Stratagene) with a wavelength of $254 \mathrm{~nm}$. After irradiation the medium was added back and the cells were allowed to recover for the indicated time periods.

\section{$R N A$ preparation and Northen blots}

RNA was prepared according to Chomczynski and Sacchi (1987) and Northern blots prepared with $5 \mu \mathrm{g}$ of total RNA per lane. The following random primed, $\alpha-{ }^{32} \mathrm{P}-\mathrm{dCTP}$ labelled DNA probes were used: $T 1$, two EcoRI-fragments $(1$ and $1.6 \mathrm{~kb}$ ) from the plasmid pT1.10, spanning the entire $T 1$ cDNA (Klemenz et al., 1989); GAPDH, a $0.8 \mathrm{~kb}$ EcoRI fragment of the chicken glyceraldehyde phosphate dehydrogenase cDNA; stromelysin, a $1.8 \mathrm{~kb}$ EcoRI/Xhol fragment from plasmid pM124 containing cDNA of murine stromelysin (kind gift of R Friis); collagenase, a $1.5 \mathrm{~kb}$ Xbal fragment from the plasmid pCllase 1 (Angel et al., 1987) containing human interstial collagenase cDNA; v-fos, a $1 \mathrm{~kb}$ Pst I fragment from the plasmid pfos-1 (Curran et al., 1982); mouse tissue factor, two EcoRI fragments of $711 \mathrm{bp}$ and $1.07 \mathrm{~kb}$ (kind gift of D Nathans); CAT, the $1.25 \mathrm{~kb}$ EcoRI/HindII fragment of the CAT gene in the plasmid pBLCAT2 (Tsonis et al., 1988). 


\section{Nuclear run-on transcription}

Approximately $6 \times 10^{7}$ cells were washed twice with phosphate-buffered-saline (PBS) and scraped into PBS. The cells were pelleted and resuspended in $\mathrm{HB}$ buffer (15 mM HEPES, pH 7.5; $60 \mathrm{~mm} \mathrm{KCl;} 15 \mathrm{~mm} \mathrm{NaCl;} 2 \mathrm{~mm}$ EDTA; $14.4 \mathrm{mM} \beta$-mercaptoethanol; $0.5 \mathrm{mM}$ spermidine; $0.5 \mathrm{mM}$ spermine; $10.3 \% \mathrm{w} / \mathrm{v}$ sucrose) supplemented with $0.5 \%$ NP-40. The nuclei were pelleted at $875 \mathrm{RCF}$ for $10 \mathrm{~min}$, resuspended in $10 \mathrm{ml} \mathrm{HB}$ buffer, pelleted again, taken up in $15 \mathrm{mM}$ HEPES (pH 7.5), $75 \mathrm{~mm} \mathrm{KCl}, 75 \mathrm{~mm}$ $\mathrm{NaCl}, 0.5 \mathrm{~mm}$ EDTA, $1.25 \mathrm{~mm}$ PMSF, $0.85 \mathrm{~mm}$ DTT, $60 \%$ glycerol and frozen in liquid nitrogen as aliquots of $2 \times 10^{7}$ nuclei. All procedures were performed at $0-4^{\circ} \mathrm{C}$. The nuclei were stored at $-80^{\circ} \mathrm{C} .2 \times 10^{7}$ nuclei were incubated at $30^{\circ} \mathrm{C}$ for $45 \mathrm{~min}$ in $90 \mathrm{mM}$ HEPES ( $\mathrm{pH} \mathrm{8.0)}$, $160 \mathrm{mM} \mathrm{KCl}, 30 \mathrm{~mm} \mathrm{NaCl}, 15 \mathrm{~mm}$ DTT, $2 \mathrm{~mm} \mathrm{MgCl}$, $1.4 \mathrm{mM} \quad$ ATP, $1.4 \mathrm{mM} \quad$ CTP, $1.4 \mathrm{~mm}$ GTP, $150 \mu \mathrm{Ci}$ $\left[\alpha^{-32} \mathrm{P}\right]$ UTP $(3000 \mathrm{Ci} / \mathrm{mmol}$, Amersham), $0.2 \mathrm{mM}$ EDTA, $0.5 \mathrm{mM} \quad \mathrm{PMSF}, \quad 0.4 \mathrm{mM} \quad \beta$-mercaptoethanol, $\quad 14.2 \mathrm{mM}$ creatine phosphate, $0.1 \mathrm{mg} / \mathrm{ml}$ creatine phosphokinase, 0.6 units RNase inhibitor and $25 \%$ glycerol. The RNA was extracted by the acid guanidinium thiocyanate-phenolchloroform method (Chomczynski and Sacchi, 1987) and pelleted. The pellet was dissolved in water and purified using the RNeasy system from Qiagen. The RNA was dissolved in formamide at $65^{\circ} \mathrm{C}$ and hybridised to a Southern blot for $17 \mathrm{~h}$ at $48^{\circ} \mathrm{C}$ in $50 \%$ formamide, $2 \times \mathrm{SSC} \quad(0.3 \mathrm{M} \mathrm{NaCl}, 34.2 \mathrm{mM} \mathrm{Na}$ citrate, $\mathrm{pH} 7.0)$, $5 \times$ Denhardt's, $1 \%$ SDS, $10 \mathrm{~mm}$ Tris-HCl $(\mathrm{pH} 7.5)$ and $100 \mu \mathrm{g} / \mathrm{ml}$ denatured carrier DNA. Southern blots were prepared with the following plasmid DNAs: pT1.10 (T1 cDNA) cut with EcoRI (Klemenz et al., 1989); pT1.28 which contains a $7.6 \mathrm{~kb}$ EcoRI fragment from genomic $T 1$ DNA spanning the region between $-6.4 \mathrm{~kb}$ and $+1.2 \mathrm{~kb}$ (Trüb et al., 1994). Restriction with EcoRI and Pst I gives rise to a $1.2 \mathrm{~kb}$ fragment from the transcribed region and three fragments of $0.8 \mathrm{~kb}, 2.3 \mathrm{~kb}$ and $3.1 \mathrm{~kb}$, from the untranscribed region. After restriction digestion the DNA fragments were size fractionated on a $1 \%$ agarose gel, denatured and transferred to a nylon membrane (GeneScreen Plus).

\section{Western blots}

Cells were lysed in sample buffer for SDS polyacrylamide gels, protein concentrations determined as described by
Schaffner and Weissmann (Schaffner and Weissman, 1973 ) and $25 \mu \mathrm{g}$ protein fractionated on $12.5 \%$ SDS polyacrylamide gels. For 2-dimensional gel analysis according to O'Farrell et al. (1977) the cells were lysed in sample buffer A (O'Farrell, 1975) and $30 \mu \mathrm{g}$ protein was used for the analysis. The primary antibodies used were directed against p38/RK phosphorylated at tyr 182, against total p38/RK (New England Biolabs) or against mouse Hsp25 (Aoyama et al., 1993). The secondary antibody was anti-rabbit immunoglobulin $G$ coupled to alkaline phosphatase (Promega). Immunocomplexes were visualised enzymatically according to the manufacturer's protocol.

\section{Plasmid construction}

The plasmid pFH6 was constructed in the following way: A $5 \mathrm{~kb} \mathrm{SacI}$ fragment containing part of exon 8 and $3.8 \mathrm{~kb}$ of the $T 1$ gene $3^{\prime}$ flanking region was cloned by blunt end ligation into the SmaI site of $\mathrm{pBC} \mathrm{SK}^{-}$(Stratagene). The coding region of the CAT gene was PCR amplified from the plasmid pBLCAT2 (Tsonis et al., 1988) using the primers $5^{\prime}$ GGGGGCGAGATTTTCAGGAGCTAAGG-3' and $3^{\prime}$ GCACCAGGCGTTTAAGGGCA-3' and was cloned as a $731 \mathrm{bp}$ fragment into the SmaI site upstream of the $3^{\prime} T 1$ gene region. A $7 \mathrm{~kb} E c o$ RI fragment from the plasmid pSH4.9, spanning $6.2 \mathrm{~kb}$ of $5^{\prime} T 1$ gene flanking sequence, the first exon and intron and part of the second exon (Trüb et al., 1994) was inserted into the EcoRI site upstream of the CAT fragment. This plasmid was cotransfected with pSV2neo into NIH3T3 cells and transfected clones were selected in medium containing G418.

\section{Note added in proof}

TNF $\alpha$ and IL-1 mediated accumulation of T1 mRNA has recently also been reported by Kumar et al. (Kumar S, Tzimas MN, Griswold DE and Young PR (1997). Biochem. Biophys. Res. Comm., 235, 474-478.

\section{Acknowledgements}

The authors would like to thank JC Lee (SmithKline Beecham) for providing SB203580, D Nathans for pGEM482, and R Friis for pM124, and D Moritz for the careful reading of this manuscript. This research was supported by the Swiss National Science Foundation (grant no. 31-41905.94 to RK).

\section{References}

Alcami A and Smith GL. (1992). Cell, 71, 153-167.

Almendral JM, Sommer D, Macdonald-Bravo H, Burckhardt J, Perera J and Bravo R. (1988). Mol. Cell. Biol., 8, $2140-2148$.

Angel P, Baumann I, Stein B, Delius H, Rahmsdorf HJ and Herrlich P. (1987). Mol. Cell. Biol., 7, 2256-2266.

Aoyama A, Fröhli E, Schafer R and Klemenz R. (1993). Mol. Cell. Biol., 13, $1824-1835$.

Aoyama A and Klemenz R. (1993). Crit. Rev. Oncog., 4, $53-$ 94.

Bergers G, Reikerstorfer A, Braselmann S, Graninger P and Busslinger M. (1994). EMBO J., 13, 1176-1188.

Beyaert R, Cuenda A, Vanden Berghe W, Plaisance S, Lee JC, Haegeman G, Cohen P and Fiers W. (1996). EMBO J., 15, 1914-1923.

Brunet A and Pouysségur J. (1996). Science, 272, $1652-$ 1655.

Cano E, Hazzalin CA, Kardalinou E, Buckle RS and Mahadevan LC. (1995). J. Cell Sci., 108, 3599-3609.

Cano E, Hazzalin CA and Mahadevan LC. (1994). Mol. Cell. Biol., 14, $7352-7362$.
Chomczynski P and Sacchi N. (1987). Anal. Biochem., 162, $156-159$.

Crête P and Landry J. (1990). Radiat. Res., 121, 320-327.

Cuenda A, Rouse J, Doza YN, Meier R, Cohen P, Gallagher TF, Young PR and Lee JC. (1995). FEBS Lett., 364, 229 233.

Curran T, Peters G, Van-Beveren C, Teich NM and Verma IM. (1982). J. Virol., 44, 674-682.

Danescu J and Werenskiold AK. (1995). FEBS Lett., 367, $89-92$.

Dérijard B, Hibi M, Wu IH, Barrett T, Su B, Deng T, Karin $\mathrm{M}$ and Davis RJ. (1994). Cell, 76, 1025-1037.

Dérijard B, Raingeaud J, Barrett T, Wu IH, Han J, Ulevitch RJ and Davis RJ. (1995). Science, 267, 682-685.

Freshney NW, Rawlinson L, Guesdon F, Jones E, Cowley S, Hsuan J and Saklatvala J. (1994). Cell, 78, 1039-1049.

Gächter T, Werenskiold AK and Klemenz R. (1996). J. Biol. Chem., 271, $124-129$.

Gayle MA, Slack JL, Bonnert TP, Renshaw BR, Sonoda G, Taguchi T, Testa JR, Dower SK and Sims JE. (1996). J. Biol. Chem., 271, 5784-5789. 
Geng Y, Valbracht J and Lotz M. (1996). J. Clin. Invest., 98, $2425-2430$.

Gould GW, Cuenda A, Thomson FJ and Cohen P. (1995). Biochem. J., 311, 735-738.

Han J, Lee JD, Bibbs L and Ulevitch RJ. (1994). Science, 265, $808-811$.

Hill CS and Treisman R. (1995). Cell, 80, 199-211.

Kalousek MB, Trüb T, Schuermann M and Klemenz R. (1994). J. Biol. Chem., 269, 6866-6873.

Klemenz R, Andres AC, Fröhli E, Schafer R and Aoyama A. (1993). J. Cell. Biol., 120, 639-645.

Klemenz R, Hoffmann S and Werenskiold AK. (1989). Proc. Natl. Acad. Sci. USA, 86, 5708-5712.

Kumar S, Minnich MD and Young PR. (1995). J. Biol. Chem., 270, 27905-27913.

Kyriakis JM, Banerjee P, Nikolakaki E, Dai T, Rubie EA, Ahmad MF, Avruch J and Woodgett JR. (1994). Nature, 369, $156-160$.

Lanahan A, Williams JB, Sanders LK and Nathans D. (1992). Mol. Cell. Biol., 12, 3919-3929.

Lau LF and Nathans D. (1991). Genes induced by serum growth factors: The hormal control regulation of gene transcription. Cohen $\mathrm{P}$ and Foulkes JG (eds). Elsevier Science Publ. B.V.: pp. 257-288.

Lee JC, Laydon JT, McDonnell PC, Gallagher TF, Kumar S, Green D, McNulty D, Blumenthal MJ, Heys JR, Landvatter SW et al. (1994). Nature, 372, 739-746.

Leevers SJ and Marshall CJ. (1992). EMBO J., 11, $569-574$.

Liang G, Wolfgang CD, Chen BP, Chen TH and Hai T. (1996). J. Biol. Chem., 271, $1695-1701$.

Ludwig S, Engel K, Hoffmeyer A, Sithanandam G, Neufeld B, Palm D, Gaestel M and Rapp UR. (1996). Mol. Cell. Biol., 16, 6687-6697.

Mahadevan LC and Edwards DR. (1991). Nature, 349, 747 748.

McLaughlin MM, Kumar S, McDonnell PC, Van-Horn S, Lee JC, Livi GP and Young PR. (1996). J. Biol. Chem., 271, $8488-8492$.

Minden A, Lin A, McMahon M, Lange-Carter C, Derijard B, Davis RJ, Johnson GL and Karin M. (1994). Science, 266, $1719-1723$.

Mitcham JL, Parnet P, Bonnert TP, Garka KE, Gerhart MJ, Slack JL, Gayle MA, Dower SK and Sims JE. (1996). J. Biol. Chem., 271, 5777-5783.

Modur V, Zimmerman GA, Prescott SM and McIntyre TM. (1996). J. Biol. Chem., 271, 13094-13102.

Moolenaar WH. (1994). TICB, 4, $213-219$.

Nahas N, Molski TFP, Fernandez GA and Sha'afi RI. (1996). Biochem. J., 318, 247-253.

O'Farrell PH. (1975). J. Biol. Chem., 250, 4007-4021.

O'Farrell PZ, Goodman HM and O'Farrell PH. (1977). Cell, 12, $1133-1141$.
Parnet P, Garka KE, Bonnert TP, Dower SK and Sims JE. (1996). J. Biol. Chem., 271, 3967-3970.

Quantin B and Breathnach R. (1988). Nature, 334, 538-539.

Raingeaud J, Gupta S, Rogers JS, Dickens M, Han J, Ulevitch RJ and Davis RJ. (1995). J. Biol. Chem., 270, $7420-7426$.

Raingeaud J, Whitmarsh AJ, Barrett T, Dérijard B and Davis RJ. (1996). Mol. Cell. Biol., 16, 1247-1255.

Reikerstorfer A, Holz H, Stunnenberg HG and Busslinger M. (1995). J. Biol. Chem., 270, 17645-17648.

Rößler U, Andres AC, Reichmann E, Schmahl W and Werenskiold AK. (1993). Oncogene, 8, 609-617.

Rößler U, Thomassen E, Hultner L, Baier S, Danescu J and Werenskiold AK. (1995). Dev. Biol., 168, 86-97.

Rouse J, Cohen P, Trigon S, Morange M, AlonsoLlamazares A, Zamanillo D, Hunt T and Nebreda AR. (1994). Cell, 78, 1027-1037.

Schaffner W and Weissmann C. (1973). Anal. Biochem., 56, $502-514$

Sims JE, Painter SL and Gow IR. (1995). Cytokine, 7, $483-$ 490.

Spriggs MK, Hruby DE, Maliszewski CR, Pickup DJ, Sims JE, Buller RM and VanSlyke J. (1992). Cell, 71, 145-152.

Symons JA, Young PR and Duff GW. (1995). Proc. Natl. Acad. Sci. USA, 92, 1714-1718.

Takagi T, Yanagisawa K, Tsukamoto T, Tetsuka T, Nagata S and Tominaga S. (1993). Biochim. Biophys. Acta., 1178, $194-200$

Tominaga S. (1989). FEBS Lett., 258, 301-304.

Tominaga S, Jenkins NA, Gilbert DJ, Copeland NG and Tetsuka T. (1991). Biochim. Biophys. Acta, 1090, 1-8.

Tominaga S, Yokota T, Yanagisawa K, Tsukamoto T, Takagi T and Tetsuka T. (1992). Biochim. Biophys. Acta, 1171, 215-218.

Trüb T, Kalousek MB, Fröhli E and Klemenz R. (1994). Proc. Natl. Acad. Sci. USA, 91, 3896-3900.

Tsonis PA, Manes T, Millan JL and Goetinck PF. (1988). Nucleic Acids Res, 16, 7745.

Werenskiold AK. (1992). Eur. J. Biochem., 204, 1041- 1047.

Werenskiold AK, Hoffmann S and Klemenz R. (1989). Mol. Cell. Biol., 9, $5207-5214$.

Whitmarsh AJ, Yang SH, Su ML, Sharrocks AD and Davis RJ. (1997). Mol. Cell. Biol., 17, 2360-2371.

Yanagisawa $\mathrm{K}$, Takagi $\mathrm{T}$, Tsukamoto $\mathrm{T}$, Tetsuka $\mathrm{T}$ and Tominaga S. (1993). FEBS Lett., 318, 83-87.

Yanagisawa $\mathrm{K}$, Tsukamoto $\mathrm{T}$, Takagi $\mathrm{T}$ and Tominaga $\mathrm{S}$. (1992). FEBS Lett., 302, 51-53.

Zervos AS, Faccio L, Gatto JP, Kyriakis JM and Brent R. (1995). Proc. Natl. Acad. Sci. USA, 92, 10531-10534.

Zinck R, Cahill MA, Kracht M, Sachsenmaier C, Hipskind RA and Nordheim A. (1995). Mol. Cell. Biol., 15, 49304938. 